\title{
POLLEN MORPHOLOGY AND TAXONOMY OF SECTION CERA- MANTHUS BAILLON S.L. OF THE GENUS PHYLLANTHUS (EUPHORBIACEAE)
}

\author{
W. PUNT \\ Laboratory of Palaeobotany and Palynology, Botanical Museum and Herbarium, State University, \\ Utrecht (The Netherlands)
}

(Received November 26, 1971)

\section{ABSTRACT}

Punt, W., 1972. Pollen morphology and taxonomy of section Ceramanthus Baillon s.L. of the genus Phyllanthus (Euphorbiaceae). Rev. Palaeobot. Palynol, 13: 213-228.

Three sections with a total number of four species of the genus Phyllanthus have been examined. The pollen grains show a strong resemblance to each other and also the taxonomic arguments to differentiate between the three sections proved to be rather weak. Because of both palynological and taxonomic reasons the sections Ceramanthus Baillon, Cluytiopsis Mueller Arg. and Anisolobium Mueller Arg. have been united into one section; viz. section Ceramanthus Baillon s.l.

\section{INTRODUCTION}

In a recent publication Airy Shaw (1969) thought it possible, that Phyllanthus albodiscus (Ridley) Airy Shaw might belong to the same circle of affinity as $P$. beillei Hutch. and $P$. welwitschianus Mueller Arg. In the same paper he published some unexpected discoveries with regard to the species P.albodiscus and $P$. beillei and, especially, the last species is of remarkable interest. It appeared that the East African species P.stolzianus Pax et K.Hoffm., P.nyassae Pax et K.Hoffm. and P.grahamii Hutchinson et M.B. Moss were not only conspecific with P.beillei from West Africa, but also with an East Asian variety of P.cochinchinensis Sprengel occurring in Thailand and Cambodia. Besides this Airy Shaw made the discovery, that Cleistanthus albodiscus Ridley and Phyllanthus ceramanthus Webster are conspecific, which was rather unfortunate so soon after the newly proposed name by Webster (1956).

As pollen morphology shows a large diversity in the genus Phyllanthus (Punt, 1967), it occurred to my mind that the features of the pollen grains might be of help to untangle the taxonomic problems in this special group of Phyllanthus species. For this reason several taxa mentioned by Airy Shaw (1969) were studied. 


\section{MATERIAL}

The material was taken from sheets which are present in the following herbaria: BR, Bruxelles (Belgium): Jardin de 1'Etat; K, Kew (Great Britain): Royal Botanic Gardens, The Herbarium and Library; L, Leiden (The Netherlands): Rijksherbarium; U, Utrecht (The Netherlands): Botanical Museum and Herbarium; WAG, Wageningen (The Netherlands): Laboratory for Plant Taxonomy and Plant Geography.

It is a pity that the $P$.beillei material from Asia does not contain male flowers (Airy Shaw, personal communication, 1971). So that it was not possible to compare the pollen grains of the Asian specimens with those of the African ones.

\section{METHODS}

\section{Preparation}

Pollen grains were prepared and mounted according to the acetolysis method as described by Reitsma (1969). The pollen grains were cut according to the method as described by Leins (1968) with the aid of a Leitz microtome which enables the cutting of sections up to $1 \mu$ thin.

\section{Descriptions}

Pollen grains were examined with a Leitz Ortholux microscope having objectives apochr. 40/0.65;100/1.32 and 90/1.40. The terminology suggested by Reitsma (1970) is used for the descriptions. Measurements have been carried out at ten pollen grains per slide. This number does not pretend to give reliable statistical values, but the figures present in a rather simple way averages and limits. They should be considered to be relative only as the influence of the preparing method together with the mounting method can be of considerable influence on the sizes of the pollen grains (Reitsma, 1970; Praglowski, 1970).

\section{Photographs}

The light microscopical photographs were taken with the same microscope equipment as that mentioned under the heading "Descriptions". This microscope was combined with a Leitz Orthomat. To increase the contrast an interference green filter AL 546 (546 nm) has been used. The film was a Kodak Recordak, AHU-microfilm 5460 film.

Besides these lightmicroscopical photographs a few scanning-electron photographs have been taken using the Cambridge equipment of the "Micro-struktuur Laboratorium" at Breukelen, The Netherlands. 


\section{TAXONOMY}

Species

\section{Phyllanthus cochinchinensis Sprengel}

P.cochinchinensis was the first species described in this special group of Phyllanthus species. Loureiro (1790) introduced it as a new monotypic genus under the name of Cathetus fasciculatus, different from Phyllanthus. Afterwards Sprengel (1826) recognized the taxon as a Phyllanthus species and he introduced the new and correct name $P$.cochinchinensis. Sprengel had to choose a complete new name as the name $P$.fasciculatus was not anymore available because of the total different taxon P.fasciculatus described by Poiret (1804) several years before. The plant is reported from East Asia growing in the North of Vietnam and the South of China up to Hong Kong.

\section{Phyllanthus albodiscus (Ridley) Airy Shaw}

The second representative was rather shortly described by Hasskarl (1844), under the name Ceramanthus gracile, as a new monotypic genus beside the genus Phyllanthus. Baillon (1858), however, considered the features of the peculiar pistil of too little value to maintain the genus Ceramanthus separately from Phyllanthus and he transferred the taxon to the latter genus. Unfortunately Roxburgh (1832) had already published another taxon under the name of Phyllanthus gracilis and consequently a new specific name was necessary. According to Airy Shaw (1969) the correct name must be $P$. albodiscus. The species is reported from the West of Java, Bangka, Malaya, up to the South of Thailand.

\section{Phyllanthus beillei Hutchinson}

This species was originally described from African material. Airy Shaw (1969) discovered that taxa with other names ( $P$. stolzianus Pax et $\mathrm{K}$. Hoffmann, $P$. nyassae Pax et $\mathrm{K}$. Hoffmann and $P$. grahamii Hutchinson et M. B. Moss) have to be considered as synonyms of $P$. beillei. At the same time he brought to light that this taxon was obviously conspecific with specimens occurring in the North of Thailand and Cambodia mentioned by Beille (1927) in the Flore Général de l'Indochine as a variety of $P$. fasciculatus (var. à feuilles plus grandes). It is remarkable, al though not unique, that a taxon can have such a disjunct area, occurring in West- and East Africa (Tanzania, Kenya in the North, to Rhodesia in the South) and also in East Asia.

\section{Phyllanthus welwitschianus Mueller Arg.}

The second African species from this group, $P$. welwitschianus, closely resembles $P$. beillei. Its distribution, however, is more restricted. The species is reported from Angola, Zambia, the South of Congo (Zaire), and the western part of Tanzania. 
Comment on the P. Beillei-P. welwitschianus complex

Airy Shaw and A. R. Smith (personal communication, 1971) suggest a combination of $P$. beillei and $P$. welwitschianus on taxonomic grounds. They have seen much African material and believe that it all belongs to one variable entity. In the material I have seen, however, there are several taxonomic differences.

P. welwitschianus: (1) plants suffruticent, arising from woody root-stocks; (2) leaves oblong-elliptic to ovate-elliptic, not elongated; with a distinctly rounded to slightly cordate base; (3) about eight lateral nerves; (4) leaves often situated face to face in the dried specimens.

P. beillei: (1) small shrubs (3-7 ft. high); (2) leaves elongately oblong-elliptic; slightly cuneate towards the base and rounded only at the base (not cordate); (3) usually more than eight lateral nerves; (4) leaves not strikingly situated face to face in the dried specimens.

On the other hand A. R. Smith wondered whether these differences make the two taxa really good species or whether it is simply a question of the biotic factor of savannah fires maintaining the sucker-shoot stage ("typical" welwitschianus, with the cordate leaves) in some areas, whereas in other areas not subject to such fires the plant is able to become a fully-developed shrub or small tree with rounded-cuneate crown leaves ("typical' beillei).

It is true, that both taxa apparently occur under quite identical ecological circumstances. The distribution of both species is, however, not quite the same.P. beillei is reported from the west-coast states; e.g., Sierre Leone, Ivory Coast, Cameroun, etc. Eastwards the species is found in Kenya up to the eastern coast at Zanzibar (Tanzania). In the eastern part of Africa the species occurs south to Rhodesia. The plants are found in lowlands as well as at higher elevations. $P$. welwitschianus is reported only from the states south of the equator, viz. Angola, southern part of Congo (Zaire), Zambia and the southwestern part of Tanzania. The plant is not found in the lowlands, but at higher altitudes.

A. R. Smith, rather uncertain about the species level of both taxa, can find one feature only that seems fairly constant. Apparently the leaves of $P$. beillei are more membranous and with more delicate venation than is to be found in $P$. welwitschianus, but here again intermediates exist. Owing to the geographical tie-up on the distribution of the two entities, and taking into account their great similarity, A. R. Smith would favour regarding them as having subspecific status. (See also Appendix 1: Note by A. R. Smith.)

\section{Sections}

The four species have been placed in three different sections; viz. P. cochinchinensis in Cluytiopsis Mueller Arg. (syn. Cathetus (Loureiro) Mueller Arg.); P. albodiscus in Ceramanthus Baillon; $P$. welwitschianus and $P$. beillei in Anisolobium Mueller Arg.

Bentham and Hooker (1880) maintain the three sections, but they point already to the 
close relationship. Pax and Hoffmann (1931), al though not mentioning any relationship, place the sections Anisolobium and Ceramanthus just after one another and the section Cathetus (i.e. section Cluytiopsis and Paraphyllanthus together) is placed nearby.

Airy Shaw (1969) was strongly attent to the affinity of $P$. albodiscus and $P$. cochinchinensis with $P$. beillei and $P$. welwitschianus. He retained, however, the sectional boundaries between Ceramanthus and Anisolobium.

Comparing the descriptions of the three sections, it is clear that they have quite a number of characteristics in common. Some of the most important ones are:

(1) Flowers rather large (about $2 \mathrm{~mm}$ ) in comparison with the flowers of other Phyllanthus species.

(2) Sepals in both sexes 6.

(3) Disk in both sexes present and in all sections the female disk is urceolate, a feature which is not at all common in the genus Phyllanthus (Webster, 1956).

(4) Stamens 3.

(5) Filaments joined into a column.

(6) Anthers free.

(7) Anthers dehiscing longitudinally.

(8) All plants are shrubs or under-shrubs. The most important differences are: (a) the disk of male flowers in the section Ceramanthus is urceolate, in the other sections the male disk consists of six separate segments; (b) form and shape of the styles are different in all three sections; (c) in the sections Anisolobium and Ceramanthus the sepals of the outer whorl differ in shape from those of the inner whorl. In the section Cluytiopsis the sepals are of the same shape and size.

One may wonder if the differences mentioned are important enough to make three different sections. In my opinion the shapes of the styles in the four species are certainly of minor importance and also the uneveness of the sepals seems less important.

The only character which might be of value seems to be the difference in either urceolate or separate disk-segments in the male flowers. However, the similarities in other features are so numerous and sometimes so striking that I advise, on taxonomic grounds, to unite the three sections to one section.

The palynological results, together with the nomenclatural consequences, are discussed below (p. 226).

\section{DESCRIPTION OF THE POLLEN GRAINS (Table I)}

\section{Phyllanthus cochinchinensis type}

Pollen Class: Pollen grains pantoporate or pantocolporate; sometimes the apertures arranged in areoles (Webster 1956).

Apertures: The number of apertures varies from 8 to 23 (rarely up to ca. 30) with 12 as most common number. Ectoapertures - usually irregular, slightly elongated pori, in shape resembling the lumina of the reticulum; these apertures sometimes small, rather narrow or 


\section{TABLE I}

Differentiating characteristics

\begin{tabular}{|c|c|c|c|c|c|}
\hline Name & Ectoaperture $^{1}$ & $\begin{array}{l}\text { Thickness of } \\
\text { the exine } \\
(\mu)\end{array}$ & $\begin{array}{l}\text { Columellae/ } \\
\text { capita }^{2}\end{array}$ & $\begin{array}{l}\text { Fusing of } \\
\text { the muri }\end{array}$ & Size \\
\hline P. albodiscus & $\mathbf{P}$ & ca. 2.5 & $=$ & dist. & $\begin{array}{l}1(30-37 \\
\mu)\end{array}$ \\
\hline P. fasciculatus & P-C & ca. 2 & longer & at top & $\begin{array}{l}\operatorname{sm}(21- \\
26 \mu)\end{array}$ \\
\hline P. "stolzianus" & P-C & ca. 3 & longer & dist. & $\begin{array}{l}\mathrm{sm}-1 \\
(22-38 \mu)\end{array}$ \\
\hline P. beillet s.s. & $\mathrm{C}$ & ca. 2 & $=$ & utmost top & $\begin{array}{l}\operatorname{sm}(21- \\
28 \mu)\end{array}$ \\
\hline P. welwitschianus & $\mathbf{C}$ & ca. 2.5 & $=$ & dist. & $\begin{array}{l}1(26- \\
47 \mu)\end{array}$ \\
\hline
\end{tabular}

' $\mathrm{P}=$ porus-like; $\mathrm{C}=$ colpus-like.

$2=$ about as long as.

${ }^{3} 1$ = large; sm = small.

narrow colpi ( $P$. welwitschianus). Margin of the apertures formed by a continuous murus of the same composition as the muri of the reticulum. Apertures not sunken and not showing any special features. Endoapertures - small, circular pori with distinct costae which are rather broad and which have diffuse margins. Pori usually smaller than the length of the ectoapertures, but slightly larger than the width of the latter.

Exine: The exine varies in thickness. Sexine always thicker than the nexine. Columellae distinct, usually longer than their capita, sometimes about as long as the capita. Capita circular to slightly elongated in optical section, laterally fused into a reticulum.

Ornamentation: Pollen grains reticulate. Reticulum fine (lumina ca. $1 \mu$ ) to rather coarse (lumina ca. $1.5 \mu$ ) or coarse (lumina ca. $2 \mu$ or more). Muri thin, simplicolumellate, fused in the upper part, columellate in the lower part; thickness of fused part varying. Lumina irregular, angular in shape, always wider than the muri breadth; width of the lumina varying.

Shape: Shape of the pollen grains irregularly cylindrical or irregularly spherical. In optical section the outline differs from irregularly elliptic to irregularly circular depending on the position in the slides.

Measurements: Longest axis varying from 20 to $40 \mu$. Number of apertures varying from 8 to over 30. Endoporus diameter varying from 2 to $3 \mu$. Exine thickness varying from 2 to $3.5 \mu$. Width of lumina varying from about $1 \mu$ up to $3.5 \mu$. 
Species

P. albodiscus (Ridley) Airy Shaw (Plate I, 1-7)

Teysman s.n., Anno 1860, Java (L); Teysman s.n., Anno 1867, Java (L); specimen from Utrecht herbarium Java, s.n.; s.c., U 36876

Number of apertures varying from 8 to 13. Shape of ectoapertures irregular, porus-like, rather broad. Exine about $2.5 \mu$ thick. Reticulum fine to rather coarse; muri distinctly fused in upper part; lumina usually ca $1 \mu$, sometimes up to $2.5 \mu$. Columellae about as long as capita or slightly longer; capita spherical in optical section. Longest axis $30-37 \mu$. Distinctly irregular in shape.

P. cochinchinensis Sprengel (Plate I, 8; Plate II, 1-3)

Coert 1218, Hong Kong (L); To Kang Ping 13658, Kwantung, China (L.).

Number of apertures varying from 9 to 12 . Shape of ectoapertures irregular, porus-like or colpus-like, rather broad. Exine about $2 \mu$ thick. Reticulum fine to rather coarse; muri fused in the upper part only; lumina usually ca $1 \mu$, sometimes up to $1.5 \mu$. Columellae distinctly longer than capita; capita small and spherical in optical section. Longest axis $21-26 \mu$. Distinctly irregular in shape.

\section{P. beillei Hutchinson ("stolzianus")-(Plate IV)}

Chase 6799, Rhodesia (BR); Milne-Redhead 3688, Zambia (BR); Graham 1986 (Type of P. grahamii), Kenya (L); Stolz 1895 (Cotype of $P$. stolzianus) (WAG).

Number of apertures varying from 11 to 20, but usually in the range of 11-14. Ectoapertures irregular elongated pori, or very short, rather broad colpi. Exine $2.5-3.8 \mu$ thick. Reticulum rather coarse to coarse; muri distinctly fused in the upper part; lumina usually ca. $2 \mu$, up to $3.5 \mu$. Columellae longer than capita; capita small, spherical to slightly elongate in optical section. Longest axis $22-38 \mu$. Distinctly irregular in shape.

\section{P. beillei Hutchinson (beillei s.s.) - (Plate III, 3-7)}

Tehe 329, Côte d'Ivoire (BR); J. J. F. E. de Wilde 735, Côte d'Ivoire (WAG)

Number of apertures varying from 12 to 27 . Ectoapertures narrow to rather broad, short colpi. Exine about $2 \mu$ thick. Reticulum rather coarse; muri fused in the uppermost part only, nearly fractured; lumina usually ca. $1.5 \mu$, sometimes up to $2 \mu$. Columellae about as long as capita, or slightly longer. Capita small and spherical. Longest axis $21-27 \mu$. Ornamentation nearly pilate. Shape of the pollen is less irregular than the other species; the grains are more spherical. 


\section{PLATE I}

Phyllanthus albodiscus (Ridley) Airy Shaw, Teysman s.n., 1860. (X 1900.)

1. Optical section of grain which is more or less cylindrical.

2. Reticulum, muri distinctly fused, lumina irregular in shape.

3. Reticulum, muri simplicolumellate.

4. Optical section of a more or less spherical pollen grain.

5. Ectoaperture, irregular, porus-like.

6. Endoaperture under the ectoaperture of 5 .

7. Section showing columellae about as high as the spherical capita.

Phyllanthus cochinchinensis Sprengel.

8. Section showing columellae which are higher than the small and spherical capita.

\section{PLATE II(p. 222)}

Phyllanthus cochinchinensis Sprengel. ( $\times$ 1900.)

1. Optical section, pollen grain irregular in shape.

2. Reticulum, muri simplicolumellate.

3. Reticulum with ectoaperture, irregular and porus-like.

Phyllanthus welwitschianus Mueller Arg.

4. Optical section of a more or less cylindrical pollen grain (Schmitz 284).

5. Ectocolpus, narrow and elongated.

6. Ectocolpus in lower position, distinctly fused muri of the reticulum.

7. Five elongated ectocolpi arranged in an areole (Richards 1077).

8. Drummond et al. 7215 , scanning photograph of a pollen grain with narrow colpi. $(\times 2000$.)

9. Section showing thick, short columellae which are about as high as, or slightly shorter than the spherical capita.

PLATE III (p. 223)

Phyllanthus welwitschianus Mueller Arg.

1. Milne-Redhead 8848, scanning photograph of a pollen grain showing short, rather broad colpi arranged in an areole. ( $\times$ 2000.)

2. Scanning photograph of the ectocolpus in higher magnification. ( $\times 7500$.

Phyllanthus beillei Hutchinson s.s. (X 1900.)

3. De Wilde 735 , reticulum, muri only fused at the top.

4. Reticulum, muri simplicolumellate.

5. Tehe 329 , ectoaperture, colpus-like, short and rather broad.

6. Ectoaperture, colpus at lower position.

7. De Wilde 735 , optical section, exine thin with low columellae and small capita, shape of the pollen grain rather regular.

PLATE IV (p. 224)

Phyllanthus beillei Hutchinson ("stolzianus"). (X 1900.)

1. Graham 1986, optical section of an irregular pollen grain.

2. Chase 6799 , ectoaperture and reticulum, muri distinctiy fused.

3. Ectoaperture, colpus-like, irregular and rather broad.

4. Section showing high columellae and small spherical to slightly elongated capita.

5. Milne-Redhead 3688 , optical section of a rather large irregular pollen grain.

6. Stolz 1895, endoporus, circular and with distinct costae.

7. Reticulum, muri simplicolumellate.

8. Reticulum, muri distinctly fused, irregular colpus.

9. Ectoaperture, colpus-like and irregular. 


\section{PLATE I}
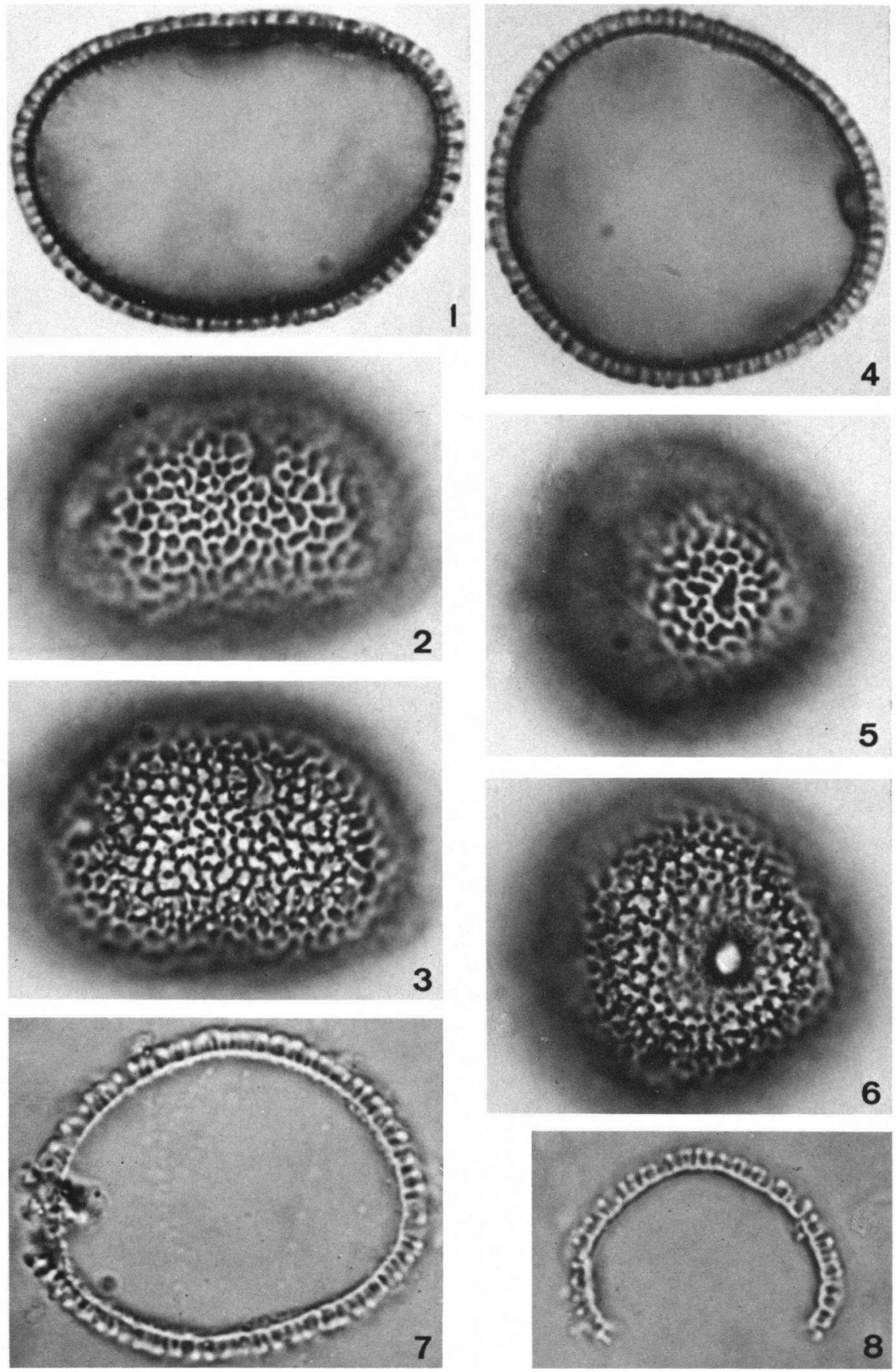


\section{PLATE II}
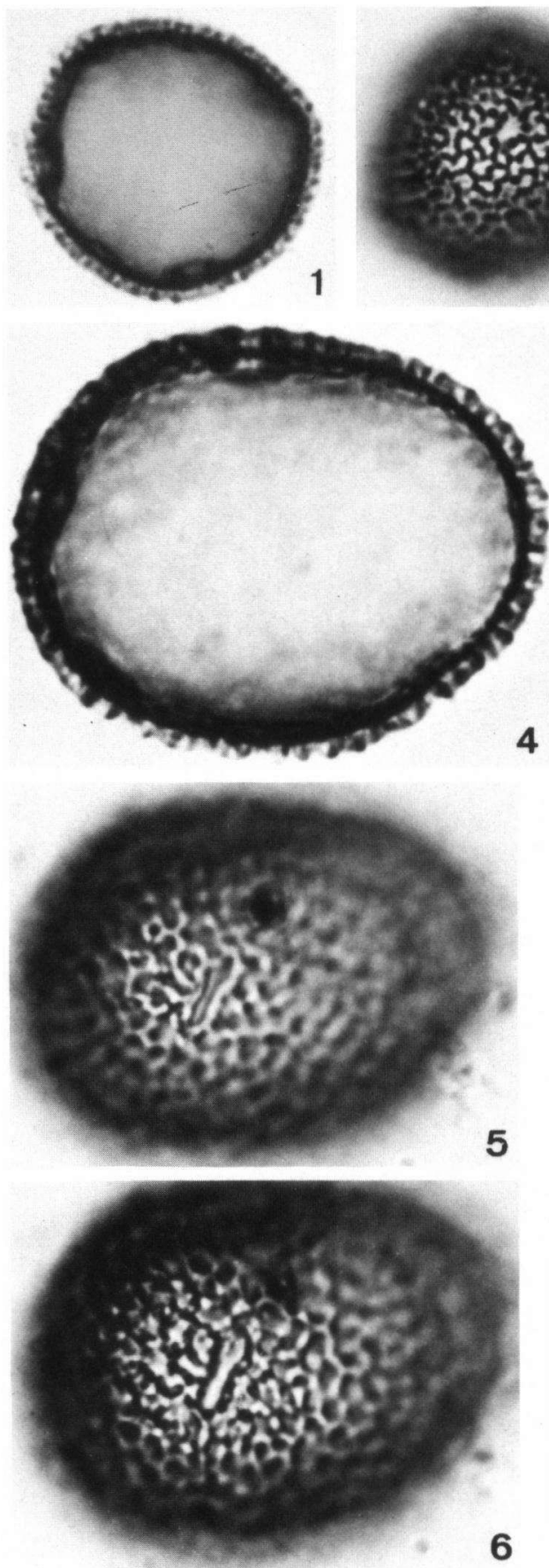
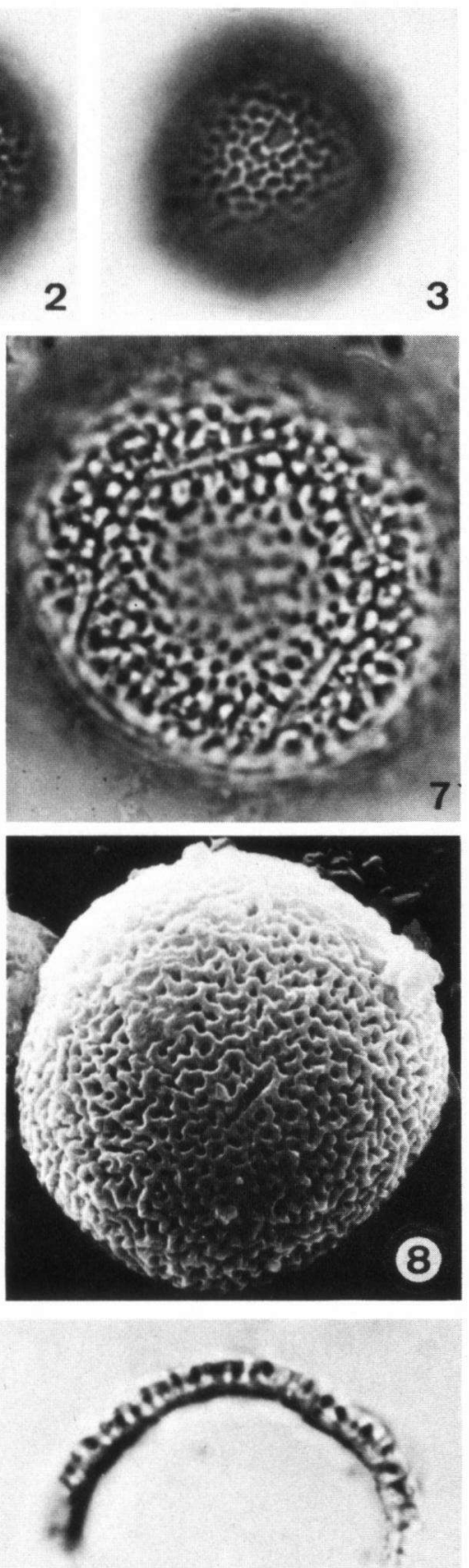

9

(For legend see p. 220.) 


\section{PLATE III}
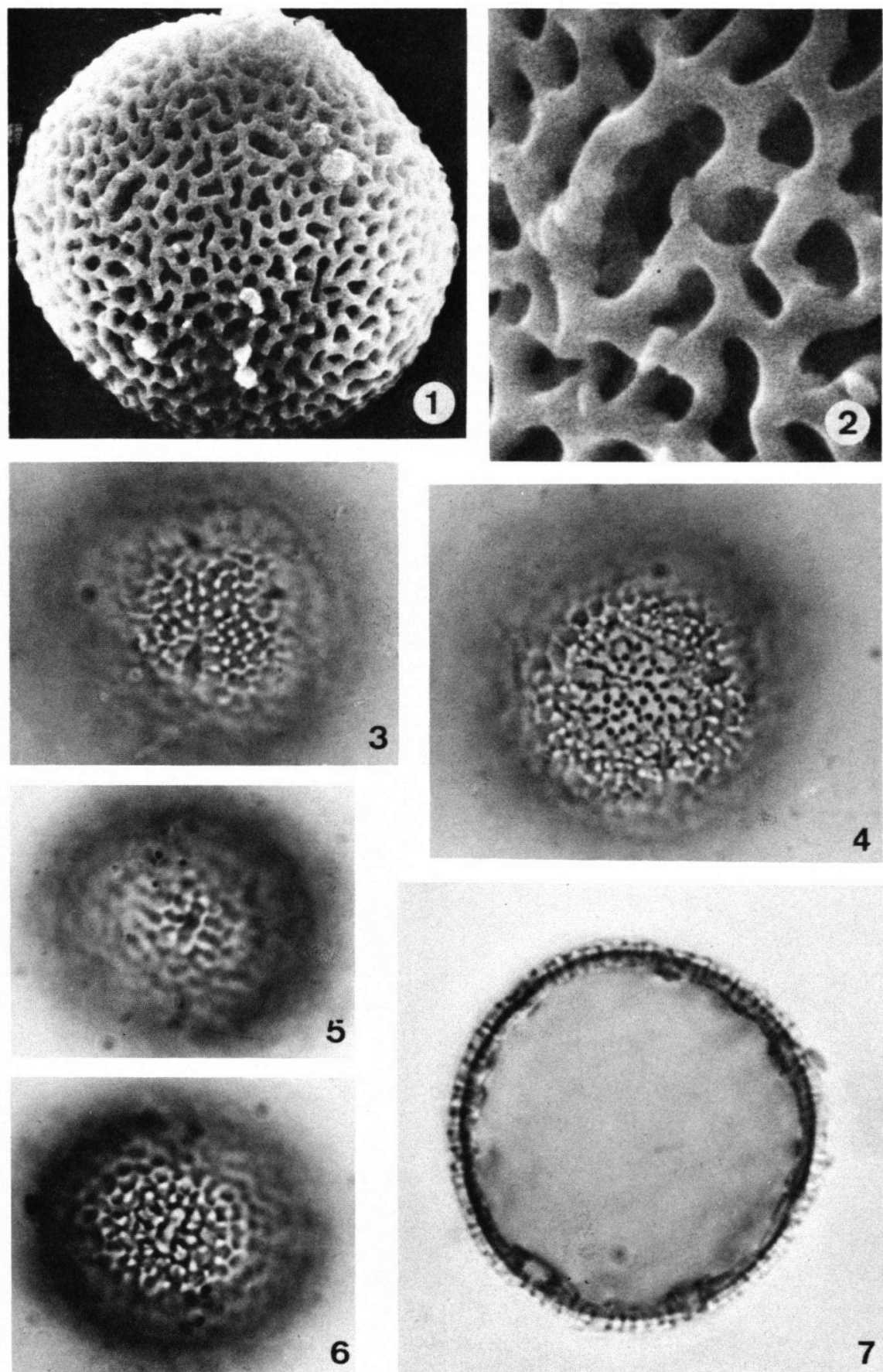

(For legend see p. 220.) 


\section{PLATE IV}
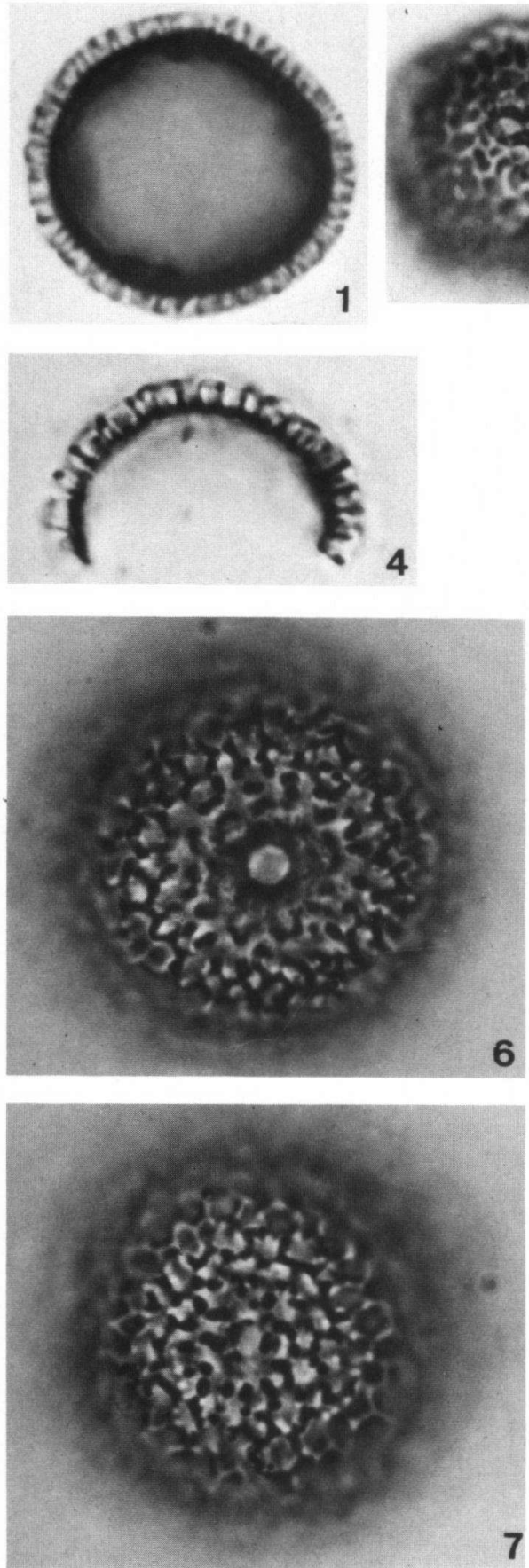

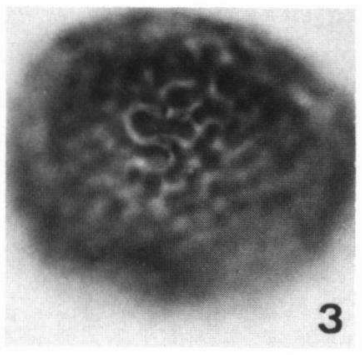

3
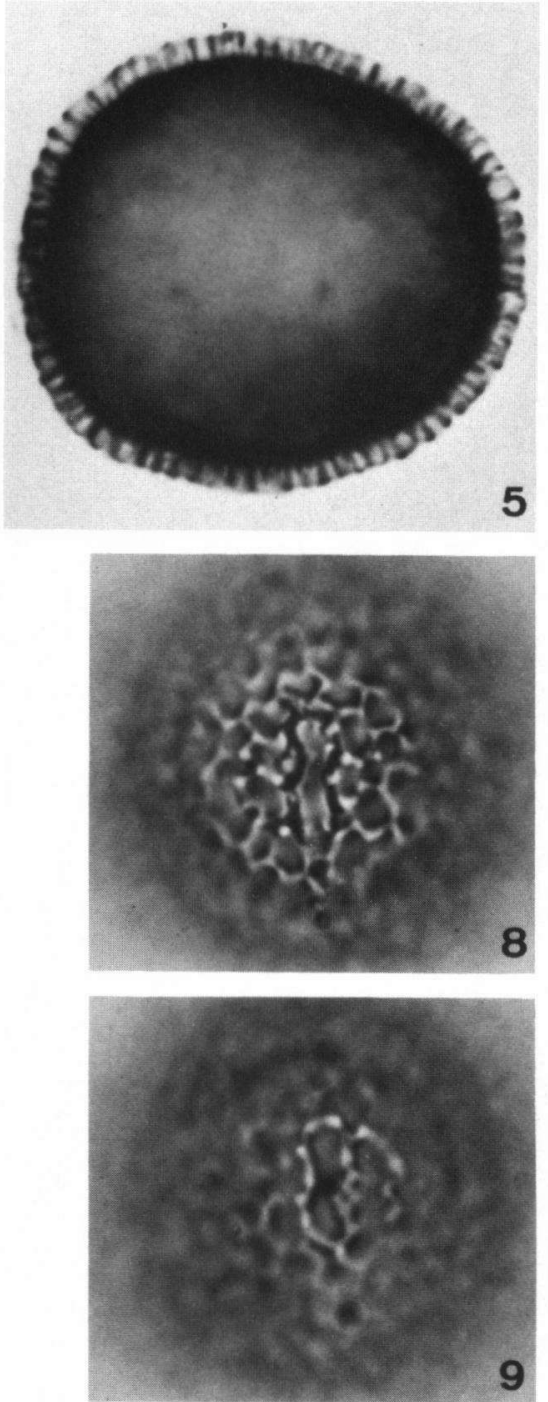

(For legend see p. 220.) 
P. welwitschianus Mueller Arg. (Plate II, 4-9); plate III, 1-2)

Baum 648, Angola (BR); R. G. M. Young 1047, Angola (BR); Drummond and Rutherford-Smith 7215, Zambia (BR); Mitchell 13/7, Zambia (BR); Richards 278, Zambia (BR); Richards 1077, Zambia (BR); Schmitz 284, Congo (Zaire) (BR); Detilleux 547, Congo (Zaire) (BR); Milne-Redhead and $P$. Taylor 8848 , Tanzania (BR).

Number of apertures varying from 13 to more than 30 , but usually in the range of 16-20 apertures. Ectoapertures always colpi which can be narrow or slightly broadened, usually arranged in areoles. Exine $2-3 \mu$ thick. Reticulum rather coarse; muri distinctly fused in the upper part; lumina ca $1.5 \mu$, sometimes up to $2 \mu$. Columellae as long as capita or slightly longer. Capita robust, in optical section spherical. Longest axis $26-47 \mu$, usually about $35 \mu$. Distinctly irregular in shape.

\section{POLLEN MORPHOLOGY}

Pollen grains of the four species show a great similarity in shape, apertural characters and ornamentation. The pollen grains differ only in minor points from species to species.

$P$. welwitschianus and $P$. albodiscus show a great similarity in shape and size, and the exine characters are very much alike. The most distinctive differences are found in the ectoapertures which are short, narrow but distinct colpi and more or less regularly arranged in 5- or 6-angular figures in $P$. welwitschianus, whereas the ectoapertures in $P$. albodiscus are irregular, porus-like apertures which do not show any regular arrangement. The regular arrangement in $P$. welwitschianus can be compared with the areoles as described by Webster (1956) and Erdtman (1952). Areolate pollen grains are known from many New World species (Webster, 1956) and from the section Macraea (P. sandwicensis, P. virgatus, etc.) occurring in the Old World. In my opinion the ornamentation in $P$. welwitschianus can be compared best with the areoles in the section Macraea, as the pollen grains in this section have their endoapertures in the middle of the colpus like in $P$. welwitschianus. "In the New World species the areolate pollen grains have their endoapertures at the ends of the syncolpate colpi in the angles of the areoles (Webster, 1956).

$P$. cochinchinensis differs from $P$. albodiscus in several characteristics: (1) in $P$. cochinchinensis the muri are fused in the uppermost part only, while in $P$. albodiscus the muri are distinctly fused; (2) the columellae are distinctly larger than the capita in $P$. cochinchinensis, while in $P$. albodiscus the columellae are about as long as the capita; (3) $P$. cochinchinensis is smaller in size than $P$. albodiscus, this difference is, however, not of much importance.

$P$. fasciculatus resembles in many respects $P$. beillei and the most striking difference is found in the reticulum. $P$. cochinchinensis has a fine to rather coarse reticulum, while $P$. beillei shows a rather coarse to coarse reticulum.

P. beillei shows pollen grains of two different kinds. An eastern kind, which I should like to call for convenience $P$. "stolzianus" and a westem one which I call $P$. beillei s.s. $P$. "stolzianus" is easily recognizable by its thick exine, distinctly fused muri, irregular, 
very short, broad elongated pori and a distinctly irregular shape. $P$. beillei $\mathrm{s.s.}$ has pollen grains with a less thick exine, a short, rather broad, but distinct colpus and a reticulum of which the muri are fused in the uppermost part only. This reticulum is nearly retipilate; the shape is only slightly irregular. $P$. "stolzianus" resembles $P$. fasciculatus in quite a number of characteristics, but differs from it by the much thicker exine and the slightly coarser reticulum. $P$. beillei s.s. has the main characteristics in common with the pollen grains of the other species, but its pollen grains do not show so much resemblance to the other species in the minor details.

It is remarkable that pollen grains of the western specimens of $P$. beillei show differences with those of the eastern specimens ( $P$. "stolzianus"). All specimens, however, certainly belong to one taxon, viz. P. beillei, s.l. Apparently pollen morphology is of less importance within the species $P$. beillei. According to this supposition, pollen morphology may be of little help in solving the problems in the $P$. beillei-P. welwitschianus complex. On the other hand, unlike the tendency in the taxonomic features, not one specimen shows pollen grains intermediate between "welwitschianus" and "stolzianus". Also the problematical, more or less intermediate specimens, show either typical "welwitschianus" pollen grains (Richards 278, Robson 1102) or typical "stolzianus" pollen grains (Faulkner 3165).

Although small differences occur between the pollen grains of the four mentioned species, it is obvious that they all belong to one entity, the Phyllanthus cochinchinensis type. However, one may wonder if there is any other species in this large genus showing the same or almost the same characters. I have seen over 300 species up to this moment and not any of them show pollen grains of the same kind. As far as I can judge from the material I have seen, the $P$. cochinchinensis type stands rather apart and cannot be compared with any other type in the genus Phyllanthus.

\section{CONCLUSIONS}

(1) The taxonomy of the four species does not give enough fundamental differences to maintain three sections. The only differential characteristic which may be of sectional value is present in the male flowers of $P$. albodiscus (sect. Ceramanthus). The urceolate disk is perhaps a strong argument to uphold two distinct sections, although there are many more characteristics in common with the other sections, which always have a male disk consisting of disk-segments.

(2) The pollen grains of all species are so much alike, that they undoubtedly belong to the same pollen type. There are only minor differences which are not sufficiently important to differentiate them into more types. These minor differences, however, can be used to differentiate between the species.

(3) Since Webster (1956) laid great emphasis on the pollen morphology within the genus Phyllanthus and as he usually mentioned the pollen characters as one of the differentiating characters for subgenera and sections it seems justified to use the pollen results as one of the most important characters to unite the three sections. 
(4) Taxonomy and pollen morphology leads me to the conclusion that the sections Anisolobium, Ceramanthus and Cluytiopsis have to be united in one large section. For nomenclatural reasons this section has to be named Ceramanthus Baillon.

\section{ACKNOWLEDGEMENTS}

The author wishes to express his sincere thanks to Dr A. R. Smith (Royal Botanic Gardens, Kew) for his valuable advice and for his kindness to send interesting material. In particular he is grateful to Professor Dr F. P. Jonker for criticizing the manuscript. He is indebted to Mrs G. Coomans-van der Mark for her technical assistance; to Mr H. E. Elsendoorn for his help in photographical matters; to Mr T. Schipper for his skillful arrangement of the plates and to Mrs Ch. M. van Wessem-Alvares Vega for her careful typewriting. Finally he is much indebted to the directors of the herbaria at Brussels, Leiden, Kew and Wageningen for their kindness in supplying the author with all the material he asked for.

\section{REFERENCES}

Airy Shaw, H. K., 1969. New or noteworthy species of Phyllanthus L. Kew. Bull. (R. Bot. Gardens), 23: $26-40$.

Baillon, H., 1858. Étude générale du Groupe des Euphorbiacées. Libraire de Victor Masson, Paris, $684 \mathrm{pp}$.

Beille, L., 1927. Phyllanthus. In: M. H. Lecomte (Editor), Flore générale de lTndo-Chine, Masson, Paris, 5: 571-608.

Bentham, G. and Hooker, J. D., 1880. Genera Plantarum, 3(1). Heeve and Co., London, 459 pp.

De Loureiro, J., 1790. Flora Cochinchinensis. Ulyssipone, 745 pp.

Erdtman, G., 1952. Pollen Morphology and Plant Taxonomy. 1. Angiosperms. Almqvist and Wiksell, Stockholm, 539 pp.

Hasskarl, J. C., 1844. Catalogus Plantarum in Horto Botanico Bogoriense Culturam Alter. Lands Drukkerij, Batavia, 391 pp.

Leins, P. 1968. Eine einfache Methode zur Herstellumg von Schnitten durch azetolysierte Pollenkörner. Grana Palynol., 8: 252-254.

Pax, F. and Hoffmann, K., 1931. Euphorbiaceae, Phyllanthus. In: A. Engler and Harms (Editors), Die Natürlichen Pfanzenfamilien. Engelmann, Leipzig, 2nd ed., pp. 60-66.

Poiret, J. L. M., 1804. In: J. Lamarck (Editor), Encyclopédie Méthodique Botanique, 5. Agasse, Paris, 748 pp.

Praglowski, J., 1970. The effects of pre-treatment and the embedding nedia on the shape of pollen grains. Rev. Palaeobot. Palynol., 10: 203-208.

Punt, W., 1967. Pollen morphology of the genu Phyllanthus (Euphorbiaceae). Rev. Palaeobot. Palynol., 3: 141-150.

Reitsma, Tj., 1969. Size modification of recent pollen grains under different treatments. $R e v$. Palaeobot. Palynol., 9: 175-202.

Reitsma, Tj., 1970. Suggestions towards unification of descriptive terminology of Angiosperm pollen grains. Rev. Palaeobot. Palynol., 10: 39-60.

Roxburgh, W., 1832. Flora Indica, 3. Allen and Co., London, 655 pp.

Sprengel, K., 1826. Systema Vegetabilium, 3. Librariae Dieterichianae, Göttingen, 832 pp.

Webster, G. L., 1956. A monographic study of the West Indian species of Phyllanthus. J. Arnold Arbor. (Harvard Univ.), 37: 217-256. 


\section{APPENDIX 1}

\section{Note by A. R. Smith'}

Although extreme forms of the two African Phyllanthus species which form part of the subject matter of Punt's paper are fairly readily distinguishable on morphological grounds as he has indicated on p. 216, nevertheless there exist more problematical specimens which represent intermediate states, and which it is not so possible to say with certainty, on these grounds alone, to which species they belong. Thus, for example, we have Robson 1102 from the Fort Manning District of Malawi, in which although the $\delta$ shoot has the characteristic features of $P$. welwitschianus (i.e. shoots more or less unbranched, arising from a rootstock; leaves perceptibly cordate at the base; leaves situated face to face), which is borne out by the pollen, the $\&$ shoot, which is undoubtedly conspecific with the of shoot, has some features of $P$. beillei (i.e. bushy habit; leaves cuneate or more or less rounded at the base; more than eight pairs of lateral nerves), al though the low stature $(30 \mathrm{~cm}$ in height) and the fact that it arises from a woody rootstock, tend to weigh somewhat against this latter species. There does thus appear to be a certain amount of sexual dimorphism, and a botanist might be forgiven if, presented with only the 9 shoot of Robson 1102, he placed it with $P$. beillei rather than $P$. welwitschianus.

In Richards 278 from northern Zambia, which is a o specimen, we again have a mixture of features. The habit is that of $P$. beillei, and the leaves have more than eight pairs of lateral nerves and are not strikingly situated face to face; nevertheless, they are cordate at the base, which would tend to rule it out for $P$. beillei; placed side by side with Faulkner 3165, from Zanzibar, in which the leafbase is rounded, and which is $P$. beillei without a doubt, it is very difficult at first sight to appreciate that two species are represented here.

Perhaps pollen morphology is the only reliable guide to the separation of $P$. beillei and P. welwitschianus.

${ }^{1}$ Royal Botanic Gardens, Kew, Richmond, Surrey (Great Britain). 